\title{
Efek Penggunaan Gadget pada Masa Pandemi Covid-19 terhadap Perilaku Anak
}

\section{(The Effects of Using Gadgets during the Covid-19 Pandemic on Children's Behaviour)}

\author{
Ilga Maria ${ }^{1}$, Ria Novianti ${ }^{2}$ \\ Pendidikan Guru Pendidikan Anak Usia Dini, Universitas Riau \\ 1ilga.maria@lecturer.unri.ac.id, 2rianovianti.rasyad@gmail.com
}

$\begin{array}{ccc}\text { First received: } & \text { Revised: } & \text { Final Accepted: } \\ \text { 29 September 2020 } & 01 \text { October 2020 } & \text { 04 October 2020 }\end{array}$

\begin{abstract}
During the Covid-19 pandemic, school from home (SFH) policy was regulated with the aim of inhibiting the spread of the virus. The SFH process makes children interact frequently with gadgets because learning is occurred online, however in practice, they must refer to the national curriculum. This study aims to find out the effects of using gadgets during the Covid-19 pandemic on children's behavior. This research is a descriptive quantitative research. The population of the study were 74 kindergarten' students in Pekanbaru City, Riau Province. Researchers took 50\% of the population so that from 74 people, 30 children were taken to be the trial sample and the rest were the research samples, as many as 37 children. The results showed that the most dominant effect of using gadgets during the Covid-19 pandemic on children's behavior was in the compulsion indicator. For further research, it can be investigated the influence of these aspects with parenting styles.
\end{abstract}

Keywords: Gadget, Covid-19, Children's Behaviour

\begin{abstract}
Abstrak
Di masa pandemi Covid-19, kebijakan belajar di rumah (BDR) diatur dengan tujuan untuk menghambat penyebaran virus. Proses BDR tersebut membuat anak lebih sering berinteraksi dengan gadget karena pembelajaran dilakukan secara daring namun praktiknya tetap harus mengacu pada kurikulum nasional. Penelitian ini bertujuan untuk melihat efek penggunaan gadget di masa pandemi Covid-19 terhadap perilaku anak. Penelitian ini merupakan penelitian kuantitatif deskriptif. Populasi penelitian adalah beberapa TK di Kota Pekanbaru, Provinsi Riau yang berjumlah sebanyak 74 orang. Peneliti mengambil 50\% dari populasi sehingga dari 74 orang diambil sebanyak 30 orang anak untuk dijadikan sampel uji coba dan sisanya adalah sampel penelitian yaitu sebanyak 37 anak. Hasil penelitian menunjukkan bahwa efek penggunaan gadget pada masa pandemi Covid-19 terhadap perilaku anak yang paling dominan berada pada indikator compulsion. Untuk penelitian lebih lanjut dapat diteliti pengaruh aspek tersebut dengan pola asuh orang tua.

Kata Kunci: Gadget, Covid-19, Perilaku Anak
\end{abstract}

\section{PENDAHULUAN}

Pandemi Coronavirus Diseases (Covid19) telah menciptakan kebutuhan dan perlunya menjaga jarak dalam interaksi sosial (WHO, 2020). Upaya tersebut dilakukan salah satunya dengan tujuan agar sistem perawatan kesehatan tidak kewalahan akibat meningkatnya jumlah pasien yang harus dilayani. Jika semakin 
tinggi frekuensi aktivitas di luar rumah (tempat keramaian), maka seorang akan semakin rentan terkena virus (Widyaningrum et al., 2020). Hal pencegahan tersebut juga berdampak pada perubahan proses belajar mengajar anak usia dini.

Dalam keadaan normal, pembelajaran model BDR (belajar di rumah) dan BDS (belajar di sekolah) bisa relatif sama tujuan dan kualitasnya. Perbedaannya terdapat pada sarana pendukung yang digunakan. Akan tetapi, pada keadaan darurat, ketika masyarakat (termasuk anak usia dini dan guru) masih dibayangi wabah Covid-19, desain dan proses pembelajaran dalam jangka waktu lama yang diterapkan menjadi berbeda. Pembelajaran daring yang dilakukan dari rumah memiliki dampak secara psikologis pada siswa (Irawan et al., 2020). Walau demikian, kebijakan BDR yang diputuskan dengan tujuan untuk menghambat penyebaran virus dalam praktiknya tetap harus mengacu pada kurikulum nasional yang digunakan.

Proses BDR membuat anak lebih sering berinteraksi dengan gadget karena pembelajaran dilakukan secara daring. Meningkatnya intensitas pengunaan gadget dikhawatirkan akan meningkatkan angka kecanduan gadget. Kecanduan gadget dapat meningkatkan prevalensi resiko gangguan pemusatan perhatian dan hiperaktivitas. Selain itu, kecanduan gadget juga dapat mempengaruhi pelepasan hormon dopamin yang berlebihan sehingga menyebabkan penurunan kematangan pada Pre-Frontal Cortex (PFC) (Paturel, 2014).

Chen \& Chang (2008) menyebutkan bahwa ada empat aspek perilaku kecanduan. Keempat aspek tersebut adalah: (1) compulsion (kompulsif/dorongan untuk melakukan secara terus-menerus). Aspek ini merupakan tekanan kuat yang berasal dari dalam diri untuk melakukan suatu hal secara terus-menerus, dalam hal ini merupakan dorongan dari dalam diri untuk terus menggunakan gadget, (2) withdrawal (penarikan diri), yaitu suatu upaya untuk menarik diri atau menjauhkan diri dari suatu hal. Perilaku seorang pengguna gadget merasa tidak mampu untuk menarik atau menjauhkan diri dari hal-hal yang berkenaan dengan gadget, seperti halnya seorang perokok yang tidak bisa lepas dari rokok. Terdapat perasaan tidak nyaman seperti gelisah ketika tidak menggunakan gadget sehingga membuat pecandu kesulitan menarik dirinya dari hal yang disukai, (3) tolerance (toleransi). Toleransi dalam hal ini diartikan sebagai sikap menerima keadaan diri ketika melakukan suatu hal. Biasanya toleransi berkenaan dengan jumlah waktu yang digunakan atau dihabiskan untuk melakukan sesuatu yang dalam hal ini adalah menggunakan gadget. Anak yang kecanduan tidak akan berhenti menggunakan gadget hingga ia merasa puas, (4) interpersonal and health-related problems (masalah hubungan interpersonal dan kesehatan). Aspek ini melibatkan persoalan yang berkaitan dengan interaksi dengan orang lain serta masalah kesehatan. Pecandu gadget cenderung tidak menghiraukan bagaimana hubungan interpersonal yang dimiliki karena mereka hanya terfokus pada menggunakan gadget saja. Begitu pula dengan masalah kesehatan, para pecandu gadget kurang memperhatikan masalah kesehatan, seperti: waktu tidur yang kurang, tidak menjaga kebersihan badan dan pola makan yang tidak teratur.

Pada awalnya, pihak sekolah dan lembaga pendidikan telah mengeluarkan peraturan larangan bermain gadget di lingkungan sekolah. Namun, kini penggunaan gadget semakin masif di masa pandemi karena tuntutan belajar daring. 
Penggunaan gadget pada anak usia prasekolah, menurut penelitian Setianigsih (2018), berdampak pada resiko gangguan pemusatan perhatian dan hiperaktivitas. Penelitian lain juga menunjukkan terdapat dampak negatif adiksi penggunaan smartphone terhadap aspek-aspek akademik (Utami, 2019). Perilaku kecanduan gadget pada siswa juga pernah diteliti oleh Wardhani (2018), namun berfokus pada perspektif rasa hormat pada siswa SMP. Oleh karena itu, penelitian ini bertujuan untuk mengetahui efek penggunaan gadget di masa pandemi Covid-19 terhadap perilaku anak usia dini.

\section{METODE}

Penelitian ini termasuk dalam rancangan penelitian deskriptif kuantitatif. Menurut Sugiyono (2010), metode penelitian kuantitatif dapat diartikan sebagai metode penelitian yang berlandaskan pada filsafat positivisme, digunakan untuk meneliti pada populasi atau sampel tertentu, teknik pengambilan sampel pada umumnya dilakukan secara random, pengumpulan data menggunakan instrumen penelitian, analisis data bersifat kuantitatif atau statistik dengan tujuan untuk menguji hipotesis yang telah ditetapkan.

Penelitian ini dilakukan di Pekanbaru. Peneliti mengambil populasi pada beberapa TK di Kota Pekanbaru Provinsi Riau yang berjumlah 74 orang anak dengan rentang umur antara 5-6 tahun. Teknik sampling yang digunakan adalah teknik random sampling. Peneliti mengambil 50\% dari populasi. Dari 74 orang anak, 30 orang anak dijadikan sampel uji coba dan sisanya adalah sampel penelitian yaitu sebanyak 37 anak.

Analisis data yang dilakukan adalah dengan menggunakan rumus persentase (Sudjana, 2002):

$\mathrm{P}=\frac{f}{n} \times 100 \%$

Keterangan:

$\mathrm{P}=$ tingkat persentase jawaban

$\mathrm{F}=$ frekuensi jawaban

$\mathrm{N}=$ jumlah sampel

Untuk menghitung rentang sekor sesuai dengan indikator yang diberikan menggunakan formula sebagai berikut (J. Supranto, 2008):

$$
\mathrm{C}=\frac{X n-X i}{K}
$$

Keterangan

$\mathrm{C}=$ tolok ukur

$\mathrm{K}=$ banyak kelas

$\mathrm{X} \mathrm{n}=$ skor ideal tertinggi

$\mathrm{X} \mathbf{i}=$ skor ideal terendah

\section{HASIL TEMUAN}

Efek penggunaan gadget pada masa pandemi Covid-19 terhadap perilaku anak dari aspek compulsion dapat dilihat pada tabel 1.

Tabel 1 Efek Penggunaan Gadget pada Masa Pandemi Covid-19 terhadap Perilaku Anak dari Aspek Compulsion

\begin{tabular}{cccc}
\hline Kriteria & Rentang & F & $\%$ \\
\hline Banyak & $34-45$ & 6 & $16 \%$ \\
Sedang & $22-33$ & 16 & $43 \%$ \\
Sedikit & $9-21$ & 15 & $41 \%$ \\
Jumlah & & 37 & $100 \%$ \\
& & & \\
\hline
\end{tabular}


Dari data di atas, dapat disimpulkan bahwa hampir sebahagian anak tidak pernah memiliki dorongan atau tekanan untuk menggunakan gadget. Selain itu, anak tidak pernah ada dorongan untuk menggunakan gadget secara terus-menerus. Efek penggunaan gadget pada masa pandemi Covid-19 terhadap perilaku anak dari aspek withdrawal dapat dilihat pada tabel 2.

Tabel 2 Efek Penggunaan Gadget pada Masa Pandemi Covid-19 terhadap Perilaku Anak dari Aspek Withdrawal

\begin{tabular}{cccc}
\hline Kriteria & Rentang & F & $\%$ \\
\hline Banyak & $41-55$ & 3 & $8 \%$ \\
Sedang & $27-40$ & 6 & $16 \%$ \\
Sedikit & $11-26$ & 28 & $76 \%$ \\
Jumlah & & 37 & $100 \%$ \\
\hline
\end{tabular}

Berdasarkan tabel 4.3 diketahui efek cenderung menjauhkan diri dari penggunaan gadget pada masa pandemi menggunakan gadget. Efek penggunaan Covid-19 terhadap perilaku anak lebih dari gadget pada masa pandemi Covid-19 separuh anak tidak pernah memiliki terhadap perilaku anak dari aspek perasaan tidak nyaman ketika tidak tolerance dapat dilihat pada tabel 3: menggunakan gadget dan bahkan

Tabel 3 Efek Penggunaan Gadget pada Masa Pandemi Covid-19 terhadap Perilaku Anak dari Aspek Tolerance

\begin{tabular}{cccc}
\hline Kriteria & Rentang & F & $\%$ \\
\hline Banyak & $30-40$ & 3 & $8 \%$ \\
Sedang & $20-29$ & 11 & $30 \%$ \\
Sedikit & $8-19$ & 23 & $62 \%$ \\
Jumlah & & 37 & $100 \%$ \\
\hline
\end{tabular}

Berdasarkan tabel di atas diketahui efek penggunaan gadget pada masa pandemi Covid-19 terhadap perilaku anak dari aspek tolerance yang tergolong banyak sebanyak 3 orang anak atau $8 \%$, yang tergolong sedang sebanyak 11 orang anak atau $30 \%$, dan yang tergolong sedikit sebanyak 23 orang anak atau $62 \%$. Artinya, lebih dari separuh anak tidak pernah menghabiskan waktu hanya untuk menggunakan gadget saja.

Efek penggunaan gadget pada masa pandemi Covid-19 terhadap perilaku anak dari aspek interpersonal and health-related problems dapat dilihat pada tabel 4:

$\begin{aligned} & \text { Tabel } 4 \text { Efek Penggunaan Gadget pada Masa Pandemi Covid-19 } \\
& \text { terhadap Perilaku Anak dari Aspek Interpersonal a } \\
& \text { health-related problems }\end{aligned}$
\begin{tabular}{lccc}
\hline Kriteria & Rentang & F & $\%$ \\
\hline Banyak & $33-45$ & 1 & $3 \%$ \\
Sedang & $21-33$ & 13 & $35 \%$ \\
Sedikit & $9-21$ & 23 & $62 \%$ \\
Jumlah & & 37 & $100 \%$ \\
\hline
\end{tabular}

Berdasarkan tabel 4.4 diketahui efek penggunaan gadget pada masa pandemi

Covid-19 terhadap perilaku anak lebih dari separuh anak tidak pernah mengalami 
masalah dengan kesehatan atau Untuk mengetahui efek penggunaan permasalahan dengan hubungan gadget pada masa pandemi Covid-19 interpersonal walaupun memiliki terhadap perilaku anak ditinjau dari kegemaran bermain game atau melihat seluruh aspek maka dibuat rekapitulasi Youtube.

hasil analisis sebagai berikut.

Tabel 5 Rekapitulasi Efek Penggunaan Gadget pada Masa Pandemi Covid-19 terhadap Perilaku Anak

\begin{tabular}{lccc}
\hline Kriteria & Rentang & F & $\%$ \\
\hline Banyak & $137-185$ & 3 & $8 \%$ \\
Sedang & $87-136$ & 11 & $30 \%$ \\
Sedikit & $37-86$ & 23 & $62 \%$ \\
Jumlah & & 37 & $100 \%$ \\
\hline
\end{tabular}

Berdasarkan tabel 4. diketahui sebanyak 4 orang anak atau 9\%, yang gambaran efek penggunaan gadget pada masa pandemi Covid-19 terhadap perilaku anak dari aspek interpersonal and healthtergolong sedang sebanyak 12 orang anak atau $27 \%$, dan yang tergolong sedikit sebanyak 28 orang anak atau $64 \%$. related problems yang tergolong banyak

Tabel 6 Efek Penggunaan Gadget pada Masa Pandemi Covid 19

\begin{tabular}{rlr}
\multicolumn{2}{c}{ terhadap Perilaku Anak } & \\
\hline No & \multicolumn{1}{c}{ Indikator } & Persentase \\
\hline 1 & Compulsion & $14,4 \%$ \\
2 & Withdrawal & $6,6 \%$ \\
3 & Tolerance & $11,8 \%$ \\
& Interpersonal and health- & \\
4 & related problems & $8,7 \%$ \\
\hline
\end{tabular}

Berdasarkan tabel 4.6 diketahui bahwa efek penggunaan gadget pada masa pandemi Covid-19 terhadap perilaku anak ditinjau dari seluruh aspek yang paling tinggi berada pada indikator compulsion.

\section{PEMBAHASAN}

Pada aspek compulsion, terlihat hampir separuh anak tidak pernah memiliki dorongan atau tekanan untuk menggunakan gadget. Hal ini menjelaskan bahwa tidak semua anak menjadikan gadget sebagai pilihan utama untuk aktivitas mereka. Beberapa kemungkinan juga mengindikasikan, bahwa dorongan untuk menggunakan gadget secara terusmenerus juga berasal dari budaya orang tua anak. Karena diketahui bahwa banyak orangtua yang mengizinkan anaknya untuk menggunakan gadget tanpa aturan yang jelas dan pembatasan waktu. Pada dasarnya, anak usia di bawah 5 tahun, boleh diberi gadget dengan memperhatikan durasi pemakaiannya (Ferliana, 2016).

Penelitian yang dilakukan oleh Delima (2015) menunjukkan hampir semua orang tua $(94 \%)$ menyatakan bahwa anak mereka biasa menggunakan perangkat teknologi untuk bermain game. Sebagian besar anak (63\%) menghabiskan waktu maksimum 30 menit untuk sekali bermain game. Sementara $15 \%$ responden menyatakan bahwa anak bermain game selama 30 sampai 60 menit dan sisanya dapat berinteraksi dengan sebuah game lebih dari satu jam. 
Selajutnya, dari aspek withdrawal, terlihat lebih dari separuh anak tidak pernah memiliki perasaan tidak nyaman ketika tidak menggunakan gadget dan bahkan cenderung menjauhkan diri dari menggunakan gadget. Berdasarkan penelitian Feliana (2016), anak usia dini yang menggunakan gadget minimal 2 jam tetapi berkelanjutan setiap hari dapat mempengaruhi psikologis anak, misalnya, anak menjadi kecanduan bermain gadget daripada melakukan aktifitas yang seharusnya yaitu belajar.

Efek penggunaan gadget terhadap perilaku anak dari aspek tolerance tergolong banyak. Lebih dari separuh anak tidak pernah menghabiskan waktu hanya untuk menggunakan gadget saja. Menurut Sari, (2016), pemakaian gadget dikategorikan dengan intensitas tinggi jika menggunakannya dengan durasi lebih dari 120 menit /hari dan dalam sekali pemakaiannya berkisar $>75$ menit. Selain itu, dalam sehari bisa berkali-kali (lebih dari 3 kali) pemakaian gadget dengan durasi $30-75$ menit akan menimbulkan kecanduan dalam pemakaian gadget. Selain itu, penggunaan gadget dengan intensitas sedang masuk dalam kategori menggunakan gadget dengan durasi lebih dari 40-60 menit /hari dan intensitas penggunaanan dalam sekali penggunaan 2 -3 kali /hari setiap penggunaan. Intensitas yang tinggi pada penggunaan gadget memberikan dampak negatif (Rahma, 2015).

Perilaku anak dari aspek Interpersonal and health-related problems tolerance di masa pandemi Covid-19 menunjukkan lebih dari separuh anak tidak pernah mengalami masalah dengan kesehatan atau permasalahan dengan hubungan interpersonal walaupun memiliki kegemaran bermain game atau melihat youtube. Hubungan interpersonal dapat terjadi dari interaksi dan komunikasi sehingga anak pada dasarnya butuh interaksi dua arah. Oleh karena itu, belajar bersama dengan sejawat dapat mendukung semangat belajar anak karena belajar secara berkelompok berperan dalam meningkatkan motivasi dan pengetahuan (Syarfina, 2020) serta meningkatkan hasil belajar anak (Roil Umamah, 2016).

Dari segi kuantitas waktu, orangtua perlu mengawasi pemakaian gadget. Penggunaan gadget yang berlebihan pada anak akan berdampak negatif karena dapat menurunkan daya konsentrasi dan meningkatkan ketergantungan anak untuk dapat mengerjakan berbagai hal yang semestinya dapat mereka lakukan sendiri. Dampak lainnya adalah semakin terbukanya akses internet dalam gadget yang menampilkan segala hal yang semestinya belum waktunya dilihat oleh anak-anak (Chusna, 2017). Oleh karena itu, jika anak mulai kecanduan gadget maka akan berefek pada kurangnya bersosialisasi dengan lingkungan sekitarnya. Secara parsial dan simultan, intensitas penggunaan smartphone berpengaruh signifikan terhadap perilaku komunikasi (Gifary \& Kurnia N, 2015; Yuniati et al., 2015) sehingga berdampak pada psikologis anak, terutama krisis percaya diri dan perkembangan fisik.

\section{SIMPULAN}

Berdasarkan hasil penelitian, dapat ditarik kesimpulan bahwa efek penggunaan gadget pada masa pandemi Covid-19 terhadap perilaku anak yang paling dominan berada pada indikator Compulsion. 


\section{DAFTAR PUSTAKA}

Chen, C.-Y., \& Chang, S.-L. (2008). An Exploration of the Tendency to Online Game Addiction Due to User's Liking of Design Features. Asian Journal of Health and Information Sciences, 3(4), 38-51.

Chusna, P. A. (2017). Pengaruh Media Gadget Pada Perkembangan Karakter Anak. Dinamika Penelitian: Media Komunikasi Sosial Keagamaan, 17(2), 315-330.

https://doi.org/10.21274/dinamika/201 7.17.2.315-330

Delima, R., Kurnia Arianti, N., \& Pramudyawardani, B. (2015). Identifikasi Kebutuhan Pengguna Untuk Aplikasi Permainan Edukasi Bagi Anak Usia 4 sampai 6 Tahun. Jurnal Teknik Informatika Dan Sistem Informasi, 1(April), 2443-2229.

Ferliana, J. M. (2016). Meningkatkan Kemampuan Berkomunikasi Aktif pada Anak Usia Dini. PT. Luxima Metro Media.

Gifary, S., \& Kurnia N, I. (2015). Intensitas penggunaan smartphone dan perilaku komunikasi (Studi Pada Pengguna Smartphone di Kalangan Mahasiswa Program Studi Ilmu Komunikasi Universitas Telkom). Jurnal Sosioteknologi, 14(2), 170-178. https://doi.org/10.5614/sostek.itbj.2015 .14 .2 .7

Irawan, A. W., Dwisona, D., \& Lestari, M. (2020). Psychological Impacts of Students on Online Learning During the Pandemic Covid-19. KONSELI: Jurnal Bimbingan Dan Konseling (EJournal), 7(1), 53-60. https://doi.org/10.24042/kons.v7i1.638 9

Paturel, A. K. (2014). Game theory: how do video games affect the developing brains of children and teens?
Educational Forum, 36(4), 514-514. https://doi.org/10.1080/0013172720933 9022

Rahma, A. (2015). Pengaruh penggunaan smartphone terhadap aktifitas kehidupan siswa (Studi Kasus MAN 1 Rengat Barat). Jurnal Fisip, 2(2), 1-12. https://doi.org/10.1016/j.immuni.2018. 03.025

Roil Umamah. (2016). Pembelajaran eksplorasi kelompok berbasis konstruktivisme untuk meningkatkan aktivitas siswa dan hasil belajar materi sistem pernapasan manusia Roil. Jurnal Scientia Indonesia, 1(April), 3744.

Sari, T. P., \& Mitsalia, A. A. (2016). Pengaruh Penggunaan Gadget Terhadap Personal Sosial Anak Usia Pra Sekolah Di Tkit Al Mukmin. Profesi, 13(Maret), 72-78. https://doi.org/http://dx.doi.org/10.265 76/profesi.124

Setianingsih, S. (2018). Dampak Penggunaan Gadget Pada Anak Usia Prasekolah Dapat Meningkatan Resiko Gangguan Pemusatan Perhatian Dan Hiperaktivitas. Gaster, 16(2), 191. https://doi.org/10.30787/gaster.v16i2.2 97

Sugiyono. (2010). Statistik Untuk Penelitian. Alfateta.

Syarfina, S. (2020). Kemampuan mahasiswa dalam mengembangkan alat permainan edukatif berbasis perkembangan anak: Peran kelompok belajar APE. Atfāluna: Journal of Islamic Early Childhood Education, 3(1), 23-33. https://doi.org/10.32505/atfaluna.v3i1. 1639

Utami, A. N. (2019). Dampak Negatif Adiksi Penggunaan Smartphone Terhadap Aspek-Aspek Akademik Personal Remaja. Perspektif Ilmu Pendidikan, 33(1), 1-14. 
https://doi.org/10.21009/pip.331.1

Wardhani, F. P. (2018). Student gadget addiction behavior in the perspective of respectful framework. Konselor, 7(3),

116-123.

https://doi.org/10.24036/020187210018 4-0-00

WHO. (2020). Coronavirus disease (Covid-19, April 28) advice for the public. https://www.who.int/emergencies/dis e ases/novel-coronavirus-2019/advicefor-public.

Widyaningrum, N., Djayanti Putri, Y., \&
Wilopo. (2020). Gambaran penerapan physical distancing sebagai upaya menekan persebaran Covid-19 di provinsi daerah istimewa Yogyakarta. NUSANTARA: Jurnal Ilmu Pengetahuan Sosial, 7(2), 470-481.

Yuniati, Y., Yuningsih, A., \& Nurahmawati, N. (2015). Konsep Diri Remaja dalam Komunikasi Sosial melalui "Smartphone." MIMBAR, Jurnal Sosial Dan Pembangunan, 31(2), 439. https://doi.org/10.29313/mimbar.v31i2. 1552 